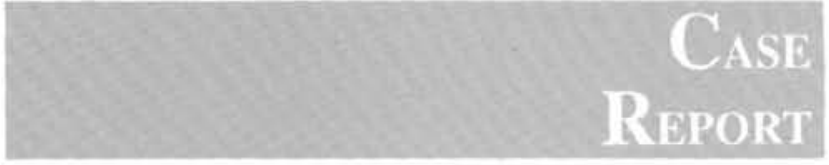

Afonso Celso Pinto Nazário, Carlos Itio Tanaka, Geraldo Rodrigues de Lima, Luiz Henrique Gebrim,

Cláudio Kemp

\title{
Leiomyoma of the breast. A case report
}

\begin{abstract}
A rare case of leiomyoma of the breast is reported, with a discussion of the clinical aspects and of the differential diagnosis. Excluding tumors originating from the areolar-papillary complex and the skin, this neoplasm is extremely rare, with only 11 cases reported so far. The histogenesis of the lesion is still controversial.
\end{abstract}

UNITERMS: Leiomyoma of the breast.

\section{INTRODUCTION}

$\mathrm{L}$ eiomyoma is a benign neoplasm involving smooth muscle which frequently occurs in the viscera of the gastrointestinal tract and in the uterus(1).

A leiomyoma originating in the stroma of the mammary gland is an extremely rare tumor, with only 11 cases reported in the literature thus far(2).

The objective of the present report is to comment on the clinical aspects of a case of leiomyoma of the breast.

\section{CASE REPORT}

A.E.S., a black woman aged 53, was seen at the Mastology Outpatient Clinic of the Discipline of Gynecology, Escola Paulista de Medicina, in September

Address for correspondence:

Afonso Celso Pinto Nazário

Rua Henrique Martins, 483 - Jardim Paulista

São Paulo/SP - Brasil - CEP 04504-000
1991. The patient had a rapidly growing tumor in the left breast which had started 12 months before.

Physical examination revealed a marked bulging in the upper and medial quadrant of the left breast. Palpation revealed a tumor of fibroelastic consistency, of welldefined limits, measuring aproximately $10 \mathrm{~cm}$ in diameter. No lymph nodes were noticed upon palpation of the axillar.

Fine-needle aspirative cytology was negative, and mammography revealed a radiopaque homogeneous image of defined and regular contours, with no internal calcifications and measuring $10 \times 7 \times 7 \mathrm{~cm}$ (Figure 1).

The clinical diagnosis was a hypercellular fibroadenoma (cystosarcoma phyllodes), which was ressected with a safety margin.

Histopathological examination revealed a mesenchymal neoplasm adjacent to blood vessels, formed by filiform and typical smooth muscle cells presenting an elongated central nucleus with a regularly arranged chromatin and an eosinophilic cytoplasm, which were arranged in bundles surrounded by dense fibrous stroma, characterizing a leiomyoma (Figure 2).

Antibodies against factor VIII and muscle actin were detected by peroxidase anti-peroxidase (PAP) and avidin methods. The results indicated the presence of an immune response of smooth muscle cells to actin. Some cells in the center of the tumor also expressed factor VIII (Figure 3). 


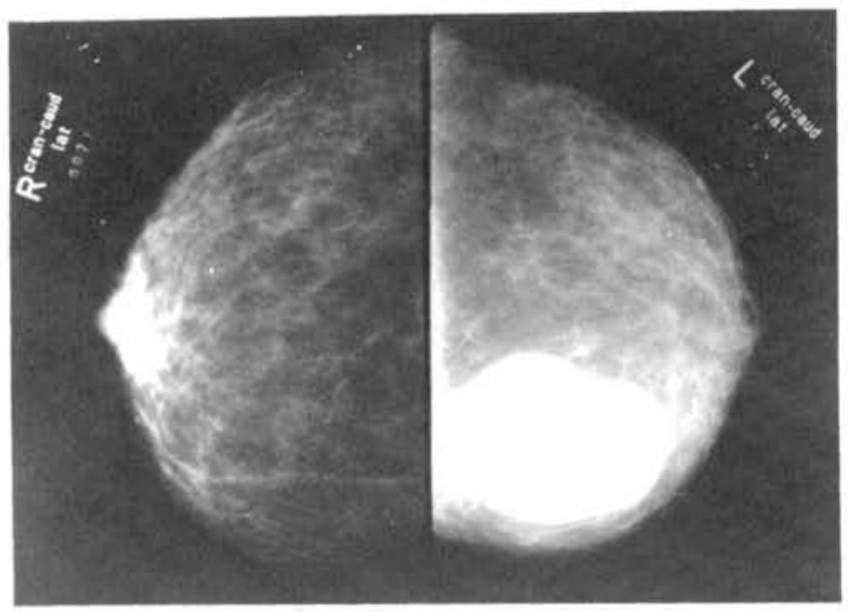

Figure 1 - Mammography showing a nodular, radio-paque image occupying the superomedial quadrant of the left breast.

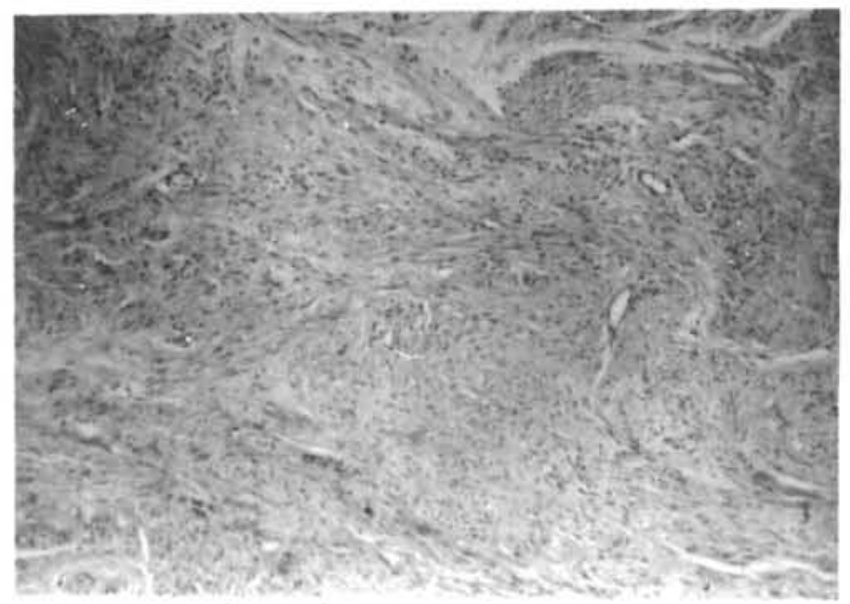

Figure 2 - Microscopic features of the lesion showing filiform smooth muscle cells with an elongated central nucleus, arranged in bundles and surrounded by dense fibrous stroma. H.E., 160x.

\section{DISCUSSION}

A mammary leiomyoma was first described by Strong in 1913.(1,3) This neoplasm is extremely rare, with only

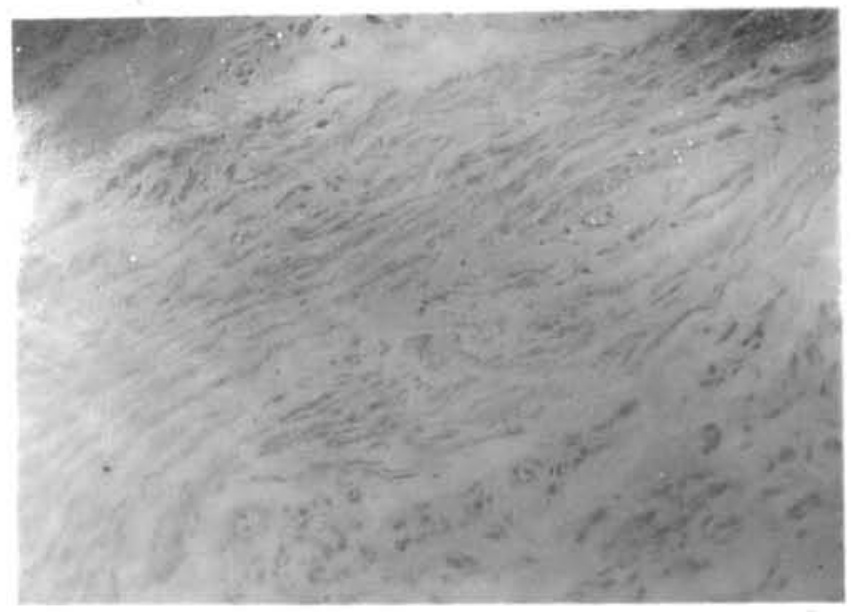

Figure 3 - Presence of an immune response of smooth muscle cells to actin. PAP, $160 x$.

11 cases reported thus far(2). The neoplasm originates in the mammary stroma, thus excluding tumors derived from retroareolar smooth muscle and from the skin.

The histogenesis of the lesion is quite controversial. Diaz Arias et al.(4) have suggested that the most likely origin may be the proliferation of smooth muscle of blood vessels. When testing for the presence of factor VIII (specific blood vessel antigen) by the immunoperoxidase technique, these researchers detected areas of positivity in the central region of the tumor.

In the present case, the histopathological and immunohistochemical findings suggest that the neoplasm may be originated from the wall of blood vessels in the mammary stroma.

The differential diagnosis is mainly made with respect to carcinoma and simple and hypercellular (cystosarcoma phyllodes) fibroadenomas. Other less frequent neoplasms should also be considered, such as histiocytoma, myoepithelioma, adenoleiomyoma, leiomyosarcoma, and primary lymphoma of the breast(5). 


\section{RESUMO}

Os autores descrevem caso de leiomioma mamário e discutem seus aspectos clínicos, a histogênese provável e o diagnóstico diferencial. Excluindo-se tumores originários do complexo aréolo-papilar e da pele, esta neoplasia é extremamente rara, com apenas 11 casos relatados na literatura.

\section{REFERENCES}

1. ALLISON, J.G.; DODDS, H.M. - Leiomyoma of the male nipple. Am. Surg. 55:501-2, 1989.

2. LAUWERS, G.; ROUX, S.; TERZAKIS, J. - Leiomyoma of the breast. Arch. Anat. Cytol. Pathol. 38:108-10, 1990.
3. LIBCKE, J.H. - Leiomyoma of the breast. J. Pathol. 98:8990, 1969.

4. ARIAS, A.A.D.; HURT, M.A.; LOY, T.S. - Leiomyoma of the breast. Hum. Pathol. 20:396-99, 1989.

5. NAZÁRIO, A.C.P.; TANAKA, C.I.; LIMA, G.R.; GEBRIM, L.H.; CHIFERI, V. - Primary Limphoma of the breast. Revista Paulista de Medicina 110(4):177-179, 1992. 